\title{
Seasonal variation in nitrification and denitrification in estuarine sediment colonized by benthic microalgae and bioturbating infauna
}

\author{
Søren Rysgaard ${ }^{1, *}$, Peter Bondo Christensen ${ }^{1}$, Lars Peter Nielsen ${ }^{2}$ \\ ${ }^{1}$ National Environmental Research Institute, Vejlsøvej 25, DK-8600 Silkeborg, Denmark \\ ${ }^{2}$ Department of Microbial Ecology, Institute of Biological Science, University of Aarhus, Ny Munkegade, Bygning 540 , \\ DK-8000 Aarhus C, Denmark
}

\begin{abstract}
Measurements of seasonal variation in oxygen fluxes, nutrient fluxes, and denitrification were obtained in an estuarine sediment inhabited by benthic microalgae and bioturbating infauna. Oxygen dynamics in the upper sediment strata were found to be controlled by the microalgae and there was a net flux of $\mathrm{O}_{2}$ out of the sediment during spring and autumn. High assimilation by the microalgae reduced the efflux of $\mathrm{NH}_{4}{ }^{+}$and $\mathrm{PO}_{4}{ }^{3-}$ from the sediment to the water column during daytime. Denitrification based on $\mathrm{NO}_{3}{ }^{-}$from the water column $\left(D_{\mathrm{w}}\right.$ ) only occurred in winter and spring, when $\mathrm{NO}_{3}{ }^{-}$ was present in the water column, and activity was proportional to the water column $\mathrm{NO}_{3}{ }^{-}$concentration. The rate of $D_{w}$ was reduced during daytime when the upper oxic zone of the sediment increased due to $\mathrm{O}_{2}$ production by benthic microalgae. Coupled nitrification-denitrification $\left(D_{n}\right)$ in the sediment was stimulated by the $\mathrm{O}_{2}$ production during winter and spring, at which times $\mathrm{NO}_{3}{ }^{-}$and $\mathrm{NH}_{4}{ }^{+}$were present in the water column in high concentrations. In contrast, during summer, when the concentration of $\mathrm{NO}_{3}{ }^{-}$and $\mathrm{NH}_{4}{ }^{+}$in the water column was low, benthic microalgae inhibited $D_{n}$ by competing with nitrifying bacteria for $\mathrm{NH}_{4}{ }^{+} . D_{\mathrm{w}}$ accounted for $80 \%$ of the total denitrification during winter, while on an annual basis, $D_{\mathrm{w}}$ and $D_{\mathrm{n}}$ each accounted for $50 \%$ of the total denitrification activity. Benthic infauna, such as Corophium spp., Hydrobia spp., and Nereis spp., occurred in densities of up to several thousand ind. $\mathrm{m}^{-2}$ from May to October. Oxygen consumption, $D_{\mathrm{w}}$ and $D_{\mathrm{n}}$ were linearly correlated with the density of the amphipod Corophium spp., all the processes studied being stimulated by the pumping of $\mathrm{O}_{2}$ - and $\mathrm{NO}_{3}{ }^{-}$-rich water through the burrows in the upper 2 to $6 \mathrm{~cm}$ of the sediment. During summer, the $D_{n}$ activity was, therefore, the net result of the inhibitory effect by benthic microalgae and the stimulatory effect of the benthic infauna. However, as the concentration of inorganic nitrogen in the overlying water and the sediment nitrification potential are both low in shallow coastal waters during summer, when benthic infauna density is high, we conclude that the stimulatory effect of bioturbating infauna on both $D_{w}$ and $D_{n}$ is of minor importance to the annual denitrification budget.
\end{abstract}

KEY WORDS: Denitrification - Nitrification - Microalgae $\cdot$ Bioturbation $\cdot$ ISN regulation

\section{INTRODUCTION}

Denitrification provides a sink in the global nitrogen budget and thereby plays an important part in controlling the degree of eutrophication in waters subjected to substantial anthropogenic input of nutrients. Denitrification in estuarine sediments thus decreases the

\footnotetext{
•E-mail: fvsr@dmu.dk
}

transport of nitrogen from land to the open sea (Seitzinger 1988). The process may be supported either by $\mathrm{NO}_{3}{ }^{-}$diffusing from the overlying water into the sediment or by $\mathrm{NO}_{3}{ }^{-}$being produced within the sediment by nitrification (Vanderborght \& Billen 1975. Nishio et al. 1983, Jenkins \& Kemp 1984). Diffusion of $\mathrm{NO}_{3}^{-}$from overlying water is mainly controlled by a concentration gradient determined by the water $\mathrm{NO}_{3}{ }^{-}$ concentration and the length of the diffusion path through the oxic zone (Christensen et al. 1990). Nitrifi- 
cation activity in sediments is mainly controlled by the availability of $\mathrm{NH}_{4}{ }^{+}$and $\mathrm{O}_{2}$, as well as by population dynamics of nitrifying bacteria (Hansen et al. 1981. Henriksen et al. 1981).

Major seasonal and diurnal variation in nitrification and denitrification in shallow water sediments is explicable by changes in oxygen penetration depth caused by benthic microalgal growth and mineralization (Christensen et al. 1990, Risgaard-Petersen et al. 1994). Nitrification is preferentially stimulated in the daytime due to photosynthetic production of oxygen and deeper oxygen penetration, while the diffusion of nitrate from the water column is stimulated during night due to high oxygen demand for mineralization and low oxygen penetration. Benthic microalgae also assimilate nitrogen and may successfully compete with nitrifiers and denitrifiers for $\mathrm{NH}_{4}{ }^{+}$and $\mathrm{NO}_{3}{ }^{-}$ (Sundbäck \& Granéli 1988, Nielsen et al. 1990, Nielsen \& Sloth 1994). In addition, nitrifying bacteria in sediment with active phototrophs may become inhibited by high $\mathrm{pH}$, high $\mathrm{O}_{2}$ concentrations, $\mathrm{CO}_{2}$ limitation, and toxic organic products (Henriksen \& Kemp 1988).

Benthic infaunal activity also affects the physical and chemical processes within sediments, e.g. through burrow building, bioturbation and irrigation (Rhoads 1974, Kristensen 1984, Aller 1988). Recently, it has been shown that the amphipod Corophium volutator stimulates oxygen uptake, denitrification of water phase $\mathrm{NO}_{3}{ }^{-}$and coupled nitrification-denitrification by mass transport of water into its burrows (Pelegri et al. 1994).

The purpose of the present study was to measure and explain the diurnal and seasonal variation in $\mathrm{O}_{2}$ consumption, nutrient fluxes, nitrification and denitrification in a shallow estuarine sediment colonized by benthic microalgae and bioturbating infauna.

\section{MATERIALS AND METHODS}

Study site. The study was carried out in Kertinge Nor, a small shallow estuary located on the east coast of the island of Funen, Denmark (Fig. 1). Kertinge Nor is connected to the sea through a narrow entrance to the east. The system receives only minor amounts of freshwater, mostly from small streams and precipitation, and the water residence time at the sampling locality is ca 4 to 6 wk (Christensen 1994). Salinity fluctuates on an annual basis but is generally around $17 \%$. During the study year, temperature varied from 2 to $4^{\circ} \mathrm{C}$ during winter up to 20 to $24^{\circ} \mathrm{C}$ during summer. The sampling site was located in shallow water $(0.5 \mathrm{~m}$ depth) where the sediment was sandy. In early spring and late autumn,

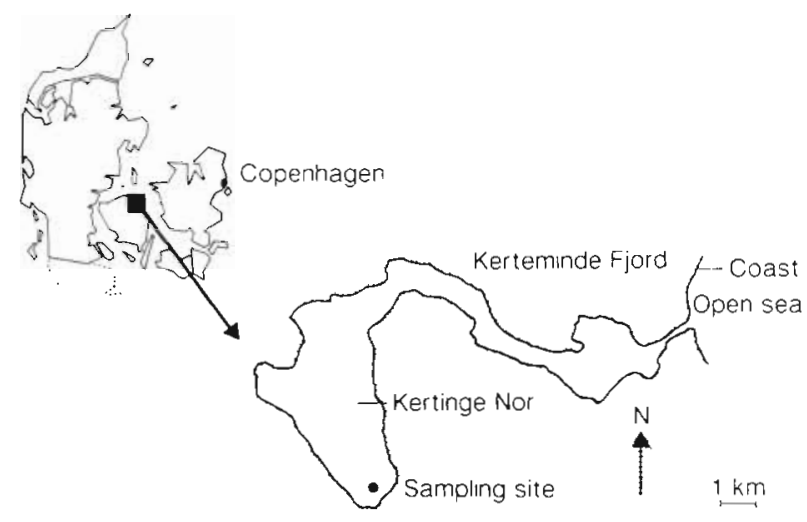

Fig. 1. Study area and sampling site in the innermost part of Kertinge Nor estuary, Denmark

a dark-brown layer of benthic microalgae was observed on the sediment surface. Amphipods (Corophium spp.) dominated the benthic fauna from May to August at densities of up to 20000 ind. $\mathrm{m}^{-2}$ Later in summer, a mixture of polychaetes (Nereis spp.), oligochaetes, mud snails (Hydrobia spp.) and amphipods (Corophium spp.) were present in the sediment at a total density of up to 50000 ind. $\mathrm{m}^{-2}$.

Sampling. The sediment was sampled on 8 different dates during 1992. On each sampling date, 16 intact sediment cores were sampled by hand in $30 \mathrm{~cm}$ long and $52 \mathrm{~mm}$ wide Plexiglas tubes and brought to the laboratory within $4 \mathrm{~h}$. In the laboratory the sediment cores were adjusted to give a sediment depth of ca $11 \mathrm{~cm}$ and a water column of $\mathrm{ca} 20 \mathrm{~cm}$. The water column was stirred by a $2.5 \mathrm{~cm}$ teflon-coated magnet positioned $5 \mathrm{~cm}$ above the sediment surface the magnets receiving momentum from an external rotating magnet $(60 \mathrm{rpm})$. The adjusted cores were left uncapped at the in situ temperature in a water bath containing $10 \mathrm{l}$ of water from the locality. Five cores were incubated in the dark and five at the in situ light conditions. During winter, spring and autumn the sediment surfaces were illuminated with ca $70 \mu \mathrm{mol}$ photons $\mathrm{m}^{-2} \mathrm{~s}^{-1}$, and during summer ca $120 \mathrm{\mu mol}$ photons $\mathrm{m}^{-2} \mathrm{~s}^{-1}$.

Flux measurements. Net fluxes of oxygen, inorganic nitrogen and inorganic phosphorus were measured by closing the cores with a rubber stopper and incubating for 1 to $12 \mathrm{~h}$ depending on the season. The incubation time was adjusted to ensure that the oxygen consumption in the cores never reduced the initial $\mathrm{O}_{2}$ concentration by more than $20 \%$. Water samples were collected just before closing the cores and after the incubation. Parallel incubated cores containing only water were used to correct for water column activity. Water samples were analyzed for $\mathrm{O}_{2}$ by Winkler titration within a few hours of sampling and GF/C filtered samples for $\mathrm{NO}_{3}{ }^{-}, \mathrm{NH}_{4}{ }^{+}$and $\mathrm{PO}_{4}{ }^{3-}$ were immediately 
frozen for later analysis. In situ fluxes of oxygen and inorganic nitrogen and phosphorus were calculated for each sediment core from the change in concentration during incubation and expressed as the rate per square meter. On several sampling dates, time series were made to ensure that the changes in oxygen and nutrient concentrations were linear over the incubation times used.

Denitrification measurements. Following measurement of the oxygen and nutrient fluxes, denitrification activity was determined on the same sediment cores by means of the isotope pairing technique (Nielsen 1992). ${ }^{15} \mathrm{NO}_{3}{ }^{-}$(20 to $60 \mu \mathrm{M}$ ) was added to the water column. However, in winter when high in situ $\mathrm{NO}_{3}{ }^{-}$concentrations were present, $250 \mu \mathrm{M}^{15} \mathrm{NO}_{3}{ }^{-}$was added in order to obtain a uniform mixing of the isotopes. The added ${ }^{15} \mathrm{NO}_{3}{ }^{-}$was allowed to equilibrate with sediment porewater $\mathrm{NO}_{3}$ - before the cores were closed with rubber stoppers. The cores were dark or light incubated for the same period as used for the flux measure. ments.

After incubation, samples of the water column and sediment porewater were collected for analysis of the ${ }^{15} \mathrm{~N}$ labelling of $\mathrm{N}_{2}, \mathrm{NH}_{4}{ }^{+}$and $\mathrm{NO}_{3}{ }^{-}$. The water column was sampled immediately upon removal of the stopper. $250 \mu \mathrm{l} \mathrm{ZnCl}$ solution ( $50 \% \mathrm{w} / \mathrm{w}$ ) was then added to the sediment surface to stop all bacterial activity and the sediment porewater and water column were carefully mixed with a Plexiglas rod. A sample of the resultant sediment slurry was taken by syringe. All samples for ${ }^{15} \mathrm{~N}$ isotope analysis were preserved in gastight containers (Exetainers, Labco, High Wycombe, UK) with $2 \%$ (vol) of the $\mathrm{ZnCl}_{2}$ solution. Finally, the sediment cores were sieved through a $1 \mathrm{~mm}$ sieve to recover the benthic infauna. Sediment porosity was measured at each sampling date in separate cores.

Test incubation. A test incubation was performed in order to find the optimal ${ }^{15} \mathrm{NO}_{3}{ }^{-}$concentration range for the denitrification measurements (Nielsen 1992). Four different concentrations of ${ }^{15} \mathrm{NO}_{3}{ }^{-}$in the overlying water $(20,40,50$ and $80 \mu \mathrm{M})$ were selected, and for each concentration, 4 intact sediment cores $\left(22 \mathrm{~cm}^{2}\right.$, $11 \mathrm{~cm}$ sediment and $20 \mathrm{~cm}$ water) were incubated as described above.

Analysis and calculations. The concentration of $\mathrm{NO}_{3}{ }^{-}$ $+\mathrm{NO}_{2}{ }^{-}$was determined on a flow injection analyzer (Tecator, Höganäs, Sweden) using the method described by Grasshoff et al. (1983). $\mathrm{NH}_{4}{ }^{+}$concentration was determined manually using the method of Bower \& Hansen (1980), and $\mathrm{PO}_{4}{ }^{3-}$ was determined by a standard colorimetric method described by Grasshoff et al. (1983). The ${ }^{15} \mathrm{~N}_{2}\left({ }^{15} \mathrm{~N}^{15} \mathrm{~N}\right.$ and $\left.{ }^{14} \mathrm{~N}^{15} \mathrm{~N}\right)$ in the water and slurry samples was extracted into a helium headspace introduced in the Exetainers. After $5 \mathrm{~min}$ of vigorously shaking most of the $\mathrm{N}_{2}$ is found in the head- space, less than $2 \%$ of the $\mathrm{N}_{2}$ gas being dissolved in the water at equilibrium. The gas in the headspace was then injected into a gas chromatograph coupled to a triple-collector isotopic ratio mass spectrometer (RoboPrep- $\mathrm{G}^{+}$in line with TracerMass, Europa Scientific, Crewe, UK) and the abundance and concentrations of ${ }^{14} \mathrm{~N}^{15} \mathrm{~N}$ and ${ }^{15} \mathrm{~N}^{15} \mathrm{~N}$ analyzed.

The production rate of the isotopes $\left[p\left({ }^{14} \mathrm{~N}^{15} \mathrm{~N}\right.\right.$ and $\left.{ }^{15} \mathrm{~N}^{15} \mathrm{~N}\right)$ ] was calculated as follows:

$$
\begin{aligned}
& p\left({ }^{14} \mathrm{~N}^{15} \mathrm{~N} \text { and }{ }^{15} \mathrm{~N}^{15} \mathrm{~N}\right)= \\
& \frac{\left[V_{1}\left(C_{\text {water }}-C_{\text {ini }}\right)|+|\left(C_{\text {slurry }}-C_{\text {ini }}\right) V_{2}\right]}{A t}
\end{aligned}
$$

where $C_{\text {waler }}$ and $C_{\text {slurry }}$ are the concentrations of the isotope in the water column and the sediment slurry, respectively, $C_{\mathrm{ini}}$ is the initial concentration of the isotope, $V_{1}$ is the volume of the sampled water, $V_{2}$ is the volume of porewater plus the remaining water column after the initial sampling, $A$ is the area, and $t$ is the incubation time.

Denitrification rates were estimated from the production of ${ }^{15} \mathrm{~N}$ isotopes (Nielsen 1992):

$$
\begin{gathered}
D_{15}=p\left({ }^{14} \mathrm{~N}^{15} \mathrm{~N}\right)+2 p\left({ }^{15} \mathrm{~N}^{15} \mathrm{~N}\right) \\
D_{14}=\frac{p\left({ }^{14} \mathrm{~N}^{15} \mathrm{~N}\right)}{2 p\left({ }^{15} \mathrm{~N}^{15} \mathrm{~N}\right)} D_{15}
\end{gathered}
$$

where $D_{15}$ and $D_{14}$ are the rates of denitrification based on ${ }^{15} \mathrm{NO}_{3}-$ and ${ }^{14} \mathrm{NO}_{3}{ }^{-}$, respectively, and $p\left({ }^{14} \mathrm{~N}^{15} \mathrm{~N}\right)$ and $p\left({ }^{15} \mathrm{~N}^{15} \mathrm{~N}\right)$ are the rates of production of the 2 labelled $\mathrm{N}_{2}$ species $\left({ }^{14} \mathrm{~N}^{15} \mathrm{~N}\right.$ and ${ }^{15} \mathrm{~N}^{15} \mathrm{~N}$, respectively). While $D_{15}$ expresses denitrification activity of added ${ }^{15} \mathrm{NO}_{3}$,,$D_{14}$ expresses the total in situ denitrification activity.

The proportion of $D_{14}$ that is based on $\mathrm{NO}_{3}{ }^{-}$from the water phase $\left(D_{\mathrm{w}}\right)$ was calculated from $D_{15}$ and the ${ }^{14} \mathrm{~N}:{ }^{15} \mathrm{~N}$ ratio of water column $\mathrm{NO}_{3}{ }^{-}$:

$$
D_{\mathrm{w}}=D_{15}\left[{ }^{14} \mathrm{NO}_{3}\right]_{\mathrm{w}} /\left[{ }^{15} \mathrm{NO}_{3}\right]_{\mathrm{w}}
$$

where $\left[{ }^{14} \mathrm{NO}_{3}{ }^{-}\right]_{\mathrm{w}}$ is the concentration of unlabelled $\mathrm{NO}_{3}{ }^{-}$and $\left[{ }^{15} \mathrm{NO}_{3}{ }^{-}\right]_{\mathrm{w}}$ the concentration of labelled $\mathrm{NO}_{3}{ }^{-}$ in the water column. Finally, in situ denitrification of $\mathrm{NO}_{3}{ }^{-}$produced by nitrification $\left(D_{\mathrm{n}}\right)$ was calculated as:

$$
D_{\mathrm{n}}=D_{14}-D_{\mathrm{w}}
$$

To estimate $D_{w}$ it was, as indicated above, necessary to measure the ${ }^{15} \mathrm{~N}$ labelling of the water column $\mathrm{NO}_{3}{ }^{-}$. A pure culture of denitrifying Pseudomonas nauticus was used to convert ${ }^{14} \mathrm{NO}_{3}{ }_{3}$ and ${ }^{15} \mathrm{NO}_{3}{ }^{-}$into $\mathrm{N}_{2}$ gas composed of ${ }^{28} \mathrm{~N}_{2},{ }^{29} \mathrm{~N}_{2}$ and ${ }^{30} \mathrm{~N}_{2}$ which was subsequently analyzed by mass spectrometry (Risgaard-Petersen et al. 1993). Labelling of $\mathrm{NO}_{3}{ }^{-}$in the water column of the sediment cores was then calculated from the ${ }^{29} \mathrm{~N}_{2} \cdot{ }^{30} \mathrm{~N}_{2}$ ratio in the analyzed gas. 


\section{RESULTS}

\section{Oxygen and nutrient fluxes}

Marked seasonal variation was abserved in the water column concentration and sediment-water flux of oxygen, inorganic nitrogen and phosphorus (Fig. 2). The benthic microalgae at the sediment surface produced $\mathrm{O}_{2}$ throughout the year, as indicated by the net efflux or reduced net uptake of $\mathrm{O}_{2}$ in the light-incubated sediment cores (Fig. 2A, B). Oxygen uptake in the dark-incubated cores, which represents the total sediment oxygen consumption, was significantly higher during the summer months of May until October (Fig. 2B). During summer, the water phase $\mathrm{O}_{2}$ concentration exceeded $100 \%$ atmospheric saturation due to $\mathrm{O}_{2}$ production by phytoplankton.

The $\mathrm{NO}_{3}{ }^{-}$concentration in the water column of Kertinge Nor displayed distinct seasonal fluctuation, the concentrations being high in winter and spring but negligible $(<0.2 \mu \mathrm{M})$ throughout the summer. $\mathrm{NO}_{3}{ }^{-}$uptake by the sediment correlated to the water column $\mathrm{NO}_{3}{ }^{-}$ concentration in both light- and darkincubated sediment (Fig. 2C, D); as a result uptake was high in spring and winter but negligible during the summer period. The water column $\mathrm{NH}_{4}^{+}$ concentration followed that of $\mathrm{NO}_{3}{ }^{-}$, although at a lower level. $\mathrm{NH}_{4}{ }^{+}$efflux from the sediment was highest during the summer, with the rate being maximal in August (Fig. 2E, F). Throughout the growth season, $\mathrm{NH}_{4}{ }^{+}$efflux was significantly lower in the light- than in the dark-incubated cores. The $\mathrm{PO}_{4}{ }^{3-}$ flux changed during the year from sediment uptake in winter to efflux during summer. Moreover, $\mathrm{PO}_{4}{ }^{3-}$ release from the sediment was higher in the darkincubated sediment ( $F i g$ 2H) than in the light-incubated sediment (Fig. 2G).

Fig. 2. Seasonal variation (1992) in $\mathrm{O}_{2}, \mathrm{NO}_{3}$ $\mathrm{NH}_{4}{ }^{+}$, and $\mathrm{PO}_{4}{ }^{3-}$ fluxes in light (open bars) and dark (solid bars) incubated sediment shown together with the respective in situ concentration. Error bars on the flux measurements indicate SE $(n=5)$

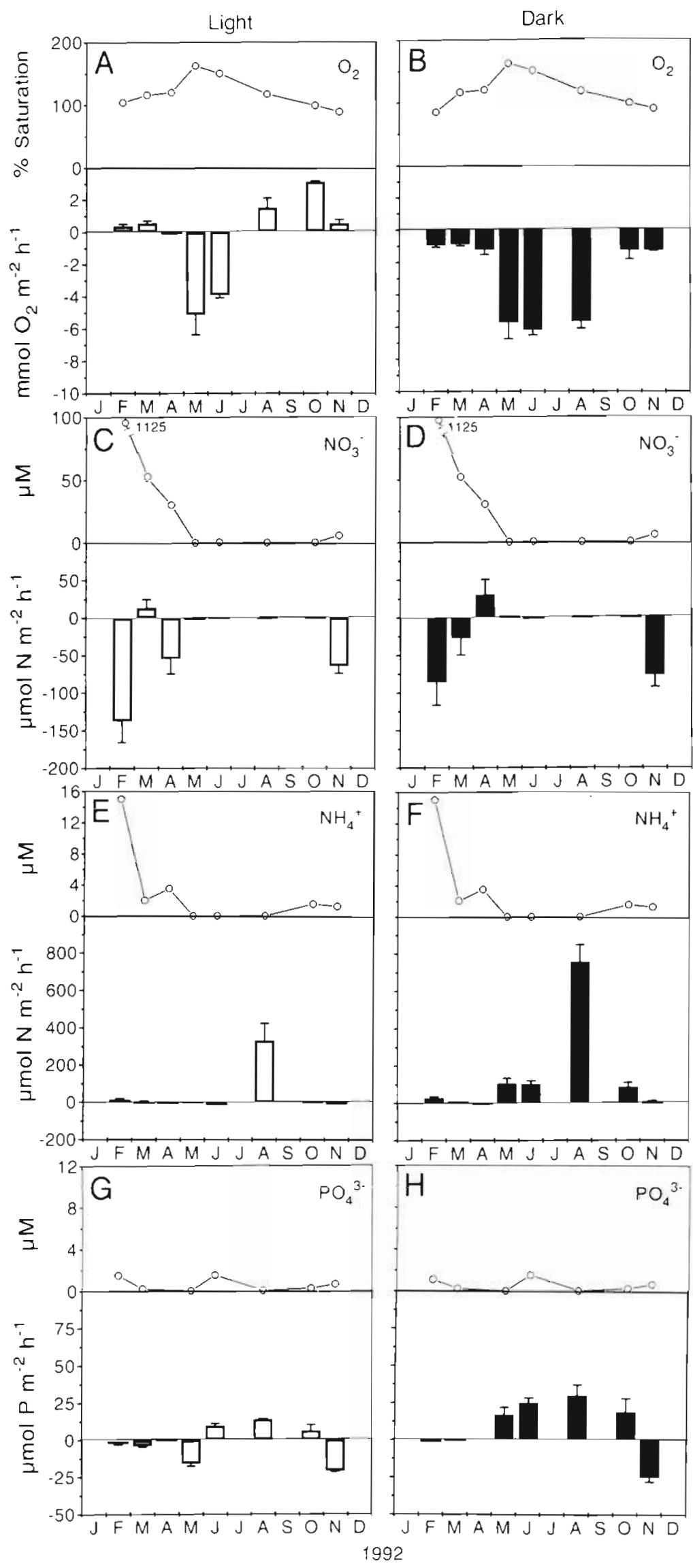




\section{Optimization of the ${ }^{15} \mathrm{NO}_{3}{ }^{-}$concentration for the denitrification assay}

Denitrification of ${ }^{15} \mathrm{NO}_{3}^{-}\left(D_{\mathrm{w} 15}\right)$ was proportional to the ${ }^{15} \mathrm{NO}_{3}{ }^{-}$concentration over the range 20 to $80 \mu \mathrm{M}$ (Fig. 3A). Further, coupled nitrification-denitrification activity $\left(D_{n}\right)$ was independent of the water column ${ }^{15} \mathrm{NO}_{3}^{-}$concentration (Fig. 3A), thus verifying that incomplete isotope mixing due to heterogeneity was not a problem (Nielsen 1992, Pelegri et al. 1994, Rysgaard et al. 1994). On this basis we concluded that addition of 20 to $80 \mu \mathrm{M}^{15} \mathrm{NO}_{3}{ }^{-}$would give real values of $D_{\mathrm{n}}$. In February, however, when the in situ $\mathrm{NO}_{3}{ }^{-}$ concentration was higher than $1000 \mu \mathrm{M},{ }^{15} \mathrm{NO}_{3}{ }^{-}$was added to a final concentration of $250 \mu \mathrm{M}$.

The concentrations of both ${ }^{14} \mathrm{~N}^{15} \mathrm{~N}$ and ${ }^{15} \mathrm{~N}^{15} \mathrm{~N}$ increased linearly with incubation time (Fig. 3B). The intercept with the $x$-axis $(y=0)$ represents the time necessary for the $\mathrm{NO}_{3}{ }^{-}$profile to stabilize within the surface sediment following addition of the ${ }^{15} \mathrm{NO}_{3}{ }^{-}$.

\section{In situ denitrification activity}

Seasonal variation in in situ denitrification is shown both as denitrification based on water phase $\mathrm{NO}_{3}{ }^{-}\left(D_{\text {w }}\right.$; Fig. 4A) and denitrification based on $\mathrm{NO}_{3}{ }^{-}$from nitrification $\left(D_{n}\right.$; Fig. $\left.4 \mathrm{~B}\right)$. In general, the rate of total denitrification $\left(D_{w}+D_{n}\right)$ was highest in late winter and
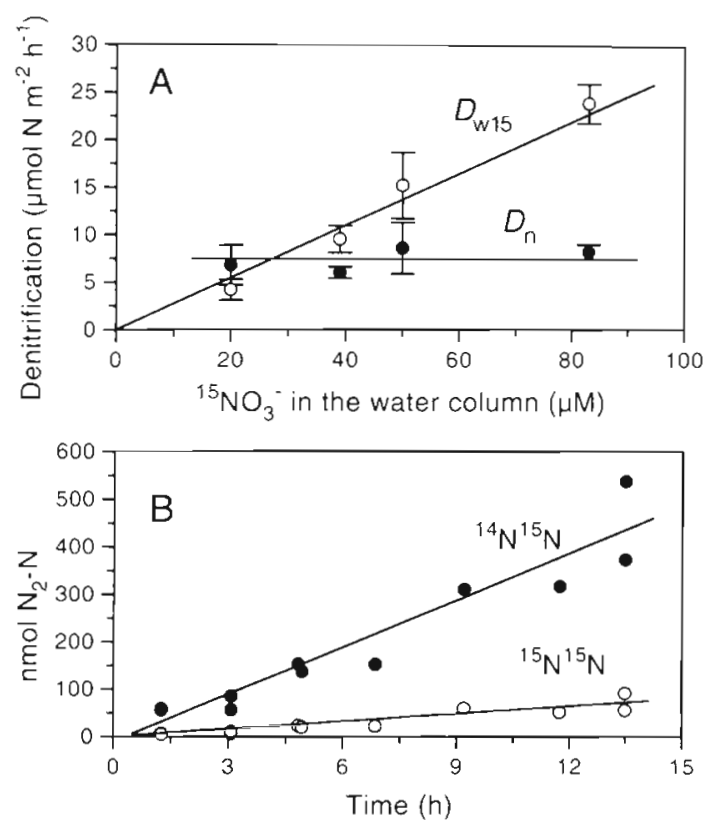

Fig. 3. (A) Denitrification of ${ }^{15} \mathrm{NO}_{3}^{-}\left(D_{\mathrm{w} 15}\right)$ and coupled nitrification-denitrification $\left(D_{\mathrm{n}}\right)$ as a function of water column ${ }^{15} \mathrm{NO}_{3}{ }^{-}$ concentration. Error bars indicate SE $(n=5)$. (B) Production of ${ }^{29} \mathrm{~N}_{2}$ and ${ }^{30} \mathrm{~N}_{2}$ as a function of time after the addition of ${ }^{15} \mathrm{NO}_{3}$. The experiment was undertaken in March at a temperature of $5^{\circ} \mathrm{C}$

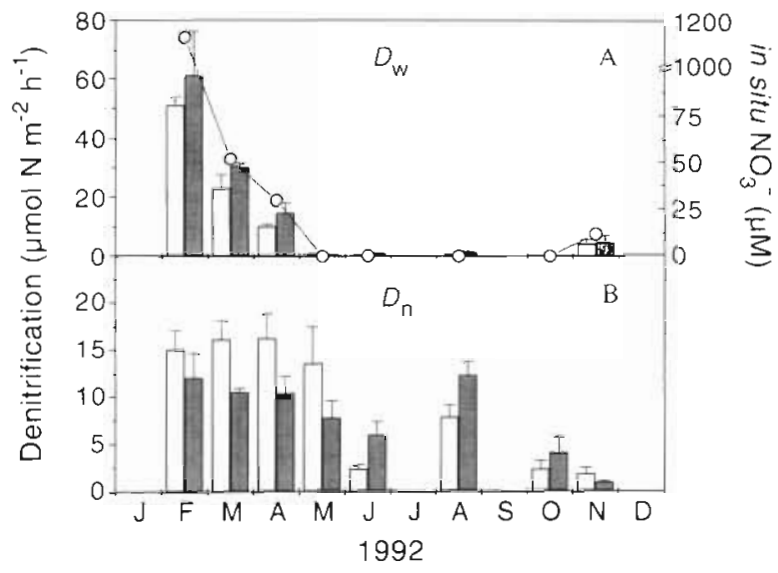

Fig. 4. Seasonal variation (1992) in (A) denitrification of $\mathrm{NO}_{3}$ from the overlying water $\left(D_{w}\right)$ and $(B)$ denitrification coupled to nitrification in the sediment $\left(D_{n}\right)$. Open and solid bars represent the rates in light-and dark-incubated sediment, respectively. In situ $\mathrm{NO}_{3}$ - concentration of the water column is given in (A). Error bars indicate SE $(n=5)$

spring in both light- and dark-incubated sediment (Fig. 4). Denitrification based on water phase $\mathrm{NO}_{3}{ }^{-}$ correlated with the $\mathrm{NO}_{3}{ }^{-}$concentration in the overlying water; it decreased from ca $60 \mu \mathrm{mol} \mathrm{N} \mathrm{m} \mathrm{N}^{-2} \mathrm{~h}^{-1}$ in February to $<1 \mu \mathrm{mol} \mathrm{N} \mathrm{m}{ }^{-2} \mathrm{~h}^{-1}$ in May and remained low throughout the summer period until the $\mathrm{NO}_{3}{ }^{-}$concentration increased in the autumn (Fig. 4A). Denitrification of water phase $\mathrm{NO}_{3}{ }^{-}$was always slightly higher in dark-incubated cores than in light-incubated cores.

Denitrification of $\mathrm{NO}_{3}{ }^{-}$produced by nitrification within the sediment was almost constant from February to June, but was lower and more variable during the rest of the year (Fig. 4B). Coupled nitrification-denitrification activity was significantly higher in light- than in dark-incubated cores during winter and spring, with the pattern being opposite in the summer period, when the concentration of inorganic nitrogen in the overlying water was very low. Coupled nitrification-denitrification accounted for ca $50 \%$ of total denitrification on an annual basis.

The presence of benthic infauna had a marked effect on oxygen consumption and denitrification rates, sediment oxygen consumption, $D_{\mathrm{w}}$ and $D_{\mathrm{n}}$ all being stimulated at increasing amphipod density (Corophium spp.) under both light and dark conditions (Fig. 5).

\section{DISCUSSION}

\section{Use of the isotope pairing technique for measuring denitrification in estuarine sediments}

Correct determination of actual in situ denitrification using the isotope pairing technique requires that 3 important assumptions are fulfilled (Nielsen 1992). 


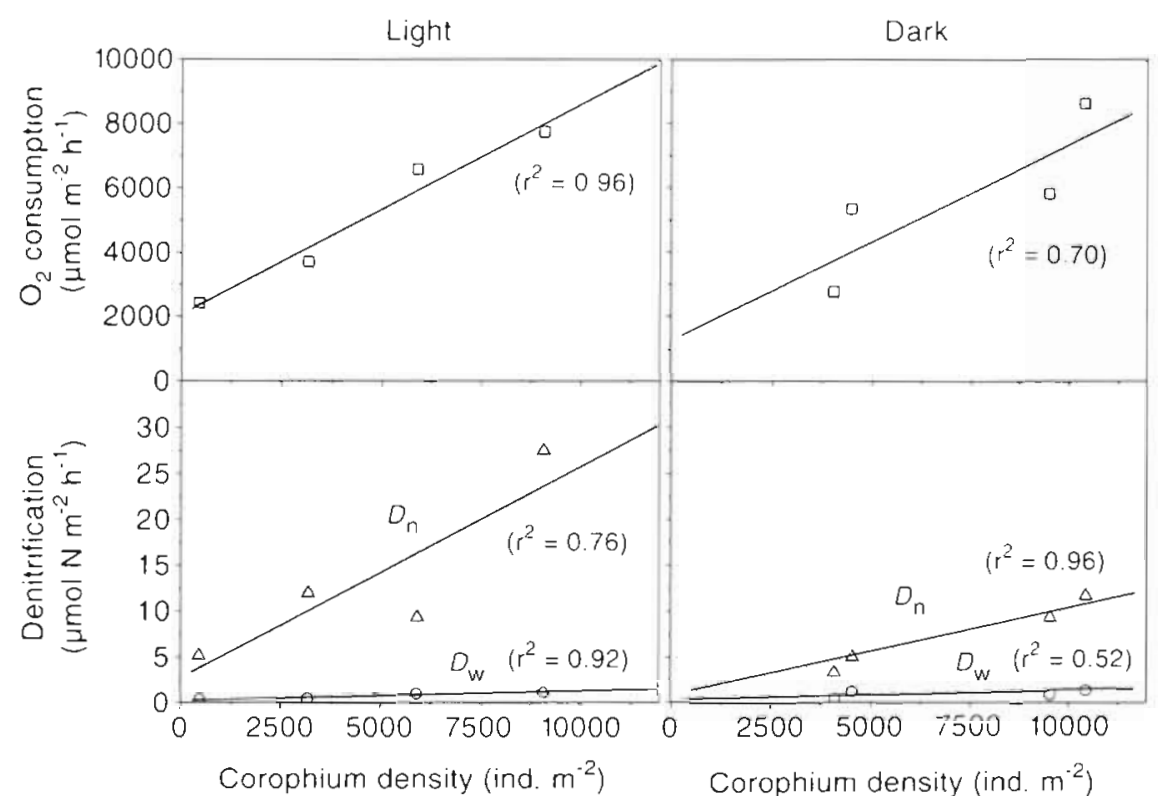

Fig. 5. Oxygen consumption denitrification based on $\mathrm{NO}_{3}^{-}$from the water column $\left(D_{\mathrm{w}}\right)$ and coupled nitrificationdenitrification $\left(D_{n}\right)$ in light and dark as a function of the density of the amphipod Corophium spp. in May 1992. Linear regressions are shown Each data point represents 1 sediment core
(1) Addition of ${ }^{15} \mathrm{NO}_{3}{ }^{-}$must not alter the rate of denitrification based on in situ $\mathrm{NO}_{3}{ }^{-}$. Microsensor and modelling studies (Christensen et al. 1989, 1990, Nielsen et al. 1990) have demonstrated a 1st order kinetic relationship between denitrification based on water phase $\mathrm{NO}_{3}{ }^{-}$and the $\mathrm{NO}_{3}{ }^{-}$concentration in the overlying water, denitrification of water phase $\mathrm{NO}_{3}$ primarily being determined by the $\mathrm{NO}_{3}{ }^{-}$concentration gradient within the upper oxic surface layer of the sediment. Since $D_{v 15}$ of the Kertinge Nor sediment was linearly correlated to the water phase ${ }^{15} \mathrm{NO}_{3}{ }^{-}$concentration (Fig. 3A), the first assumption was therefore fulfilled.

(2) The added ${ }^{15} \mathrm{NO}_{3}{ }^{-}$must mix uniformly with the $\mathrm{NO}_{3}{ }^{-}$already present in water column and in the sediment. Heterogeneous topography, bioturbation, inhomogenous nitrification activity, etc., may cause local variations in the transport of ${ }^{14} \mathrm{NO}_{3}$ and ${ }^{15} \mathrm{NO}_{3}{ }^{-}$to the anoxic denitrification zone, and hence underestimate in situ denitrification activity $\left(D_{14}\right)$ since ${ }^{14} \mathrm{~N}^{15} \mathrm{~N}$ production would then be less than that predicted on the assumptions of homogeneity (Broast et al. 1988). As demonstrated by several authors (Nielsen 1992, Pelegri et al. 1994, Rysgaard et al. 1994) this possible underestimation can be analyzed by incubating the sediment cores at different ${ }^{15} \mathrm{NO}_{3}{ }^{-}$concentrations. At increasing ${ }^{15} \mathrm{NO}_{3}{ }^{-}$concentration, an increased denitrification of ${ }^{14} \mathrm{NO}_{3}{ }^{-}$will be detected directly as ${ }^{14} \mathrm{~N}^{15} \mathrm{~N}$ on the mass spectrometer, thereby minimizing the possible underestimation of $D_{14}$. As demonstrated in the optimization experiment, coupled nitrification-denitrification was independent of the water phase $\mathrm{NO}_{3}$ concentration at concentrations greater than $20 \mu \mathrm{M}$, thus indicating uniform mixing of the added ${ }^{\prime} \mathrm{NO}_{3}$ -
(Fig. 3A). We always used a higher ${ }^{15} \mathrm{NO}_{3}{ }^{2}$ concentration, thereby ensuring correct determination of both coupled denitrification $\left(D_{n}\right)$ and total denitrification $\left(D_{14}\right)$.

(3) A stable $\mathrm{NO}_{3}{ }^{-}$concentration gradient must be established in the surface layer of the sediment within a short time of ${ }^{15} \mathrm{NO}_{3}{ }^{-}$addition relative to the duration of incubation. If this is not the case, denitrification activity will be underestimated since the added ${ }^{15} \mathrm{NO}_{3}$ will not be immediately available to the denitrifying bacteria in the anoxic zone of the sediment. The time needed to establish a stable $\mathrm{NO}_{3}{ }^{-}$gradient depends on the $\mathrm{O}_{2}$ penetration depth. During summer, when oxygen typically penetrates $1 \mathrm{~mm}$ down into shallow sediments, the $90 \%$ equilibration time is ca $5 \mathrm{~min}$ (Nielsen 1992), During winter, when the $\mathrm{O}_{2}$ penetration is deeper, the establishment of a new $\mathrm{NO}_{3}^{-}$gradient takes longer. Nevertheless, as the optimization experiment shows that production of ${ }^{15} \mathrm{~N}$-dinitrogen was linear after $30 \mathrm{~min}$ in March (Fig. 3B), the establishment of a stable $\mathrm{NO}_{3}{ }^{-}$profile took less than $30 \mathrm{~min}$, this being a short period compared to the total incubation time of up to $12 \mathrm{~h}$ during winter The third assumption was therefore also fulfilled at the Kertinge Nor sediment.

\section{Effect of benthic microalgae and infauna on oxygen and nutrient dynamics}

When benthic microalgae colonize the sediment surface of shallow waters, they may greatly influence oxygen and nutrient dynamics at the sediment-water interface. Oxygen production by benthic microalgae 
may increase the oxygen penetration into the sediment by several $\mathrm{mm}$ (Revsbech \& Jørgensen 1983) and thereby influence sediment metabolism as well as the turnover and flux of nutrients on both a diurnal and seasonal basis (Sundbäck 1986, Sundbäck \& Granéli 1988, Risgaard-Petersen et al. 1994). Even though $\mathrm{NH}_{4}{ }^{+}$was present at a high concentration in the sediment porewater, the benthic microalgae reduced the $\mathrm{NH}_{4}{ }^{+}$flux to the water column significantly as a result of nitrogen assimilation as demonstrated by Rysgaard et al. (1993). Efflux of $\mathrm{NH}_{4}{ }^{+}$was not measurable when photosynthesis was taking place, except in August (Fig. 2E). The microalgae therefore acted as an efficient filter, adsorbing the flux of ammonium from the deeper, anoxic sediment layers. Henriksen et al. (1980) and Sundbäck (1986) have also reported that a thin layer of benthic microalgae is able to control the flux of inorganic nitrogen from sediment to the overlying water. When $\mathrm{NO}_{3}{ }^{-}$was present in the water column in spring and early winter, the flux of $\mathrm{NO}_{3}{ }^{-}$was generally directed into the sediment, this being attributable to benthic assimilation in the surface layers and denitrification in the deeper sediment layers. Assimilation of inorganic nutrients by the benthic microalgae also influenced the $\mathrm{PO}_{4}{ }^{3-}$ flux, a lower efflux being observed in light- than in dark-incubated sediment. The $\mathrm{PO}_{4}^{3-}$ flux into the sediment during winter was most likely due to binding of phosphate to oxidized iron, which is more abundant within the sediment during the cold season, when oxygen demand is lower and oxygen penetration into the sediment therefore deeper (Rasmussen \& Jørgensen 1992).

Benthic oxygen production may also greatly influence sediment nitrification and denitrification. In the sediment from Kertinge Nor, we found that $D_{w}$ was slightly less in the light than in the dark (Fig. 4A). However, it has recently been demonstrated that photosynthesis by benthic microalgae reduced denitrification based on water phase $\mathrm{NO}_{3}{ }^{-}\left(D_{\mathrm{w}}\right)$ by ca $50 \%$ during the day as a result of deeper $\mathrm{O}_{2}$ penetration into the sediment when photosynthesis was taking place (Risgaard-Petersen et al. 1994). This deeper oxygen penetration enhances the diffusion path from the water column to the denitrifying zone, thereby reducing the $\mathrm{NO}_{3}{ }^{-}$supply for denitrification (Christensen et al. 1989 , Nielsen et al. 1990). The difference in inhibition of denitrification in the 2 studies can be ascribed to the relatively higher activity (as judged from the much higher $\mathrm{O}_{2}$ production) of benthic microalgae in the laboratory experiment by Risgaard-Petersen et al. (1994) as compared to our measurements of in situ activity in Kertinge Nor.

During winter and early spring when the availability of inorganic nitrogen was high, benthic photosynthesis stimulated coupled nitrification-denitrification (Fig. 4B), this probably being due to oxygen stimulation of nitrification. This is in agreement with the study of Risgaard-Petersen et al. (1994), who found that benthic microalgae stimulated $D_{n}$ during the day as a result of their $\mathrm{O}_{2}$ excretion. However, both findings are in conflict with the hypothesis of Henriksen \& Kemp (1988) that photosynthesis by benthic diatoms reduces nitrification due to a combination of a high competition for $\mathrm{NH}_{4}{ }^{+}$, high $\mathrm{pH}$ and high $\mathrm{O}_{2}$ concentration in the upper sediment layers, all of which inhibit the nitrification process, and thereby also the coupling between nitrification and denitrification. The competition between nitrifiers and benthic microalgae for inorganic nitrogen is particularly intense during periods of illumination; moreover, the concentration of available inorganic nitrogen in the overlying water and within the sediment is of major importance when evaluating the effect of benthic photosynthesis on nitrogen processes Thus, during the summer period from May until November, when both $\mathrm{NO}_{3}{ }^{-}$and $\mathrm{NH}_{4}{ }^{+}$was almost absent in the water column of Kertinge Nor, the photosynthetic activity of benthic microalgae actually reduced the activity of coupled nitrification-denitrification (Fig, 4B). Further, $D_{\mathrm{n}}$ reflected the $\mathrm{NH}_{4}{ }^{+}$efflux from the sediment (Fig. 2F), thus indicating strong competition for $\mathrm{NH}_{4}{ }^{+}$between nitrifiers and benthic microalgae in the surface layers of the sediment during the summer period, as has been suggested by Henriksen \& Kemp (1988). Since benthic microalgae can assimilate $\mathrm{NO}_{3}{ }^{-}$ and $\mathrm{NH}_{4}{ }^{+}$at high rates for up to $60 \mathrm{~h}$ after sediment has been darkened, they therefore represent an efficient competitor for nitrifying bacteria at low nitrogen concentrations (Rysgaard et al. 1993). However, when $\mathrm{NO}_{3}{ }^{-}$or $\mathrm{NH}_{4}{ }^{+}$are present at high concentrations in the overlying water column they can act as a nitrogen source for the benthic assimilatory demand, and thereby reduce the competition with nitrifiers for porewater $\mathrm{NH}_{4}{ }^{+}$. This was the situation in Kertinge Nor during winter and spring as well as in the laboratory experiments of Risgaard-Petersen et al. (1994), where benthic primary production stimulated the coupled nitrification-denitrification. Thus, as indicated by the present study, there may be both diurnal and seasonal variation in the effect of benthic microalgae on the coupling between nitrification and denitrification in estuarine sediments, i.e. microalgal photosynthesis may stimulate denitrification during the cold season, when nitrogen availability is high, and inhibit denitrification during summer, when nitrogen availability is low,

Oxygen and nitrogen dynamics within the sediment may also be affected by bioturbating infauna (Henriksen et al. 1980, Aller 1982, Kristensen et al. 1991). In the sandy sediment of Kertinge Nor, sediment oxygen respiration and denitrification was significantly enhanced at increasing densities of the amphipod Coro- 
phium spp. (Fig. 5). Stimulation of sediment oxygen consumption, $D_{n}$ and $D_{\mathrm{w}}$ in the presence of Corophium spp. can be explained by mass transport of $\mathrm{O}_{2}$ - and $\mathrm{NO}_{3}{ }^{-}$-rich water within the U-shaped amphipod burrows, which may penetrate as much as 2 to $6 \mathrm{~cm}$ into the sediment (Pelegri et al. 1994). Infauna density was particularly high from May until November (Fig. 6). During this period, the water column $\mathrm{NO}_{3}{ }^{-}$concentration was very low (Fig. 2) and the effect of bioturbating fauna on $D_{\mathrm{w}}$ was consequently negligible; the high infauna density primarily stimulated $D_{n}$ activity (Fig. 5). The stimulation of coupled nitrification-denitrification activity was higher in light, probably because the infauna were more active during the day and therefore able to pump more $\mathrm{O}_{2}$-rich water into the sediment. Coupled nitrification-denitrification activity in May

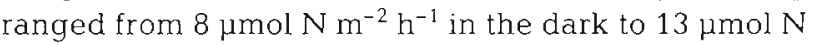
$\mathrm{m}^{-2} \mathrm{~h}^{-1}$ in the ight (Fig. 4B). From the data presented in Fig. 5, the activity in sediments devoid of Corophium spp. can be extrapolated to be less than $3 \mu \mathrm{mol} N$ $\mathrm{m}^{-2} \mathrm{~h}^{-1}$. It is therefore obvious that the presence of Corophium spp. had a marked influence on coupled nitrification-denitrification activity in Kertinge Nor during the summer period. However, total nitrification activity is generally reduced in shallow coastal waters during summer since the population of nitrifiers in the sediment is reduced due to lower $\mathrm{O}_{2}$ availability and higher $\mathrm{NH}_{4}{ }^{+}$competition (Hansen et al. 1981). As a consequence, coupled nitrification-denitrification activity was low during summer in Kertinge Nor compared to that obtained during winter (Fig. 4B). The stimulatory effect of the bioturbating infauna (mainly present during summer) on $D_{w}$ and $D_{\mathrm{n}}$ was therefore limited by the predominantly low water column $\mathrm{NO}_{3}^{-}$concentration and the reduced nitrifying population in the sediment, respectively.

Stimulation of coupled nitrification-denitrification with increasing infauna density was 2 -fold greater

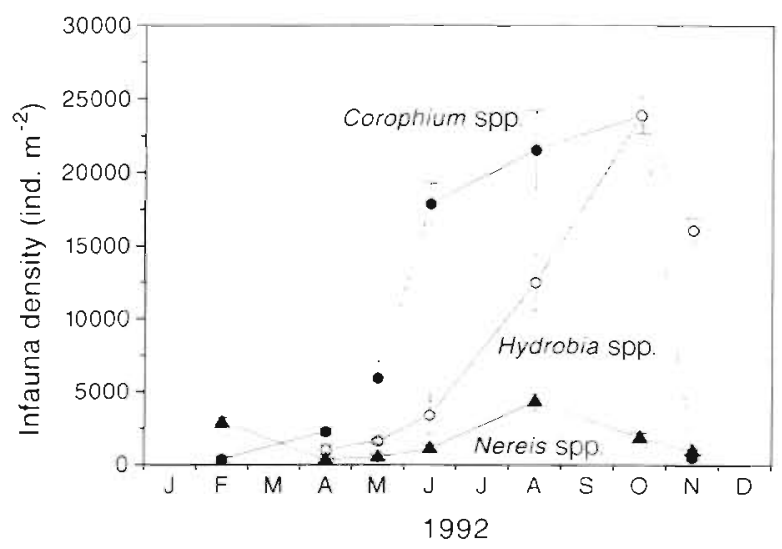

Fig. 6. Seasonal variation (1992) in benthic infauna density at the study site. Error bars indicate SE ( $\mathrm{n}=8$ to 16$)$

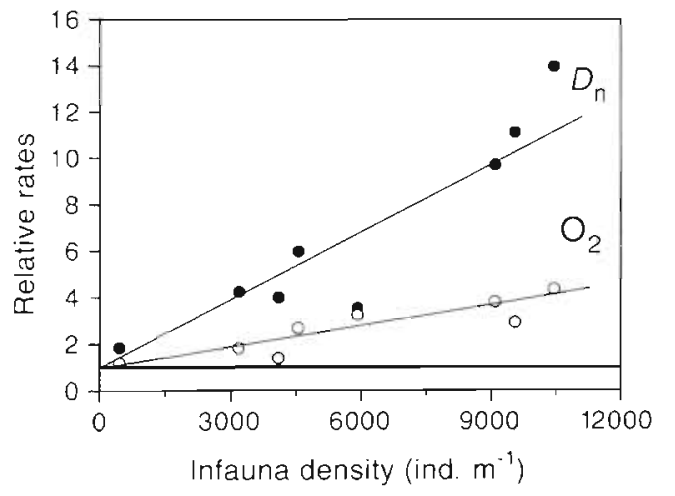

Fig. 7. Oxygen uptake and denitrification coupled to nitrification $\left(D_{n}\right)$ as a function of amphipod density. The relative rates are rates measured in bioturbated sediment cores divided by rates measured in non-bioturbated sediment cores. The horizontal line at 1 thus represents activity in amphipod-free sediment cores. Data are from both light-and dark-incubated cores

than that of $\mathrm{O}_{2}$ consumption rate (Fig. 7), a finding consistent with the observations of Pelegri et al. (1994). Nitrate produced by nitrification in a sediment devoid of bioturbating animals will diffuse both upwards to the water column and downwards to the anoxic denitrification zone; assuming homogeneous distribution of nitrifiers throughout the oxic surface layers of the sediment, approximately half of the $\mathrm{NO}_{3}{ }^{-}$will diffuse in each direction (Nielsen et al. 1990, Pelegri et al. 1994). Nitrate diffusing out of the oxic layer in an amphipod burrow can be denitrified further down the burrow, however, and coupling between nitrification and denitrification will therefore be much closer in bioturbated sediment. Thus, as a general rule, bioturbation should stimulate nitrification and sediment oxygen uptake to an equivalent extent, while coupled nitrification-denitrification should be stimulated twice as much as oxygen consumption when coupling of nitrification and denitrification is almost 100\% (Pelegri et al. 1994).

\section{Control and relative importance of $D_{w}$ and $D_{\mathrm{n}}$}

Denitrification based on water phase $\mathrm{NO}_{3}^{-}\left(D_{w}\right)$ was highly correlated to the $\mathrm{NO}_{3}^{-}$concentration in the water, activity being high during winter and spring and almost negligible throughout summer (Fig. 4A). A model relating $D_{w}$ to $\mathrm{O}_{2}$ uptake and the water column concentrations of $\mathrm{O}_{2}$ and $\mathrm{NO}_{3}{ }^{-}$(Christensen et al. 1990) was tested on the present data set. The model is based on the fact that $\mathrm{O}_{2}$ penetration within the sediment is a function of $\mathrm{O}_{2}$ concentration and $\mathrm{O}_{2}$ uptake. The $\mathrm{O}_{2}$ penetration depth represents the diffusional path for $\mathrm{NO}_{3}{ }^{-}$to the underlying, anaerobic denitrification zone 
and the concentration of $\mathrm{NO}_{3}^{-}$in the water column divided by the diffusional path of $\mathrm{NO}_{3}{ }^{-}$thus represents the concentration gradient of $\mathrm{NO}_{3}{ }^{-}$. The flux of $\mathrm{NO}_{3}{ }^{-}$to the denitrification zone can therefore be calculated by multiplying this concentration gradient with the diffusion coefficient of $\mathrm{NO}_{3}{ }^{-}$in the sediment:

$$
D_{\mathrm{w}}=F_{\mathrm{O}_{2}} \times \alpha \times\left[\left(1+\frac{D_{\mathrm{NO}_{1}}}{D_{\mathrm{O}_{2}}} \times \frac{C_{\mathrm{NO}_{3}}}{C_{\mathrm{O}_{2}}} \times \frac{1}{\alpha}\right)^{\frac{1}{2}}-1\right]
$$

where $F_{\mathrm{O}_{2}}$ is the sediment oxygen consumption, $\mathrm{C}_{2}$ and $\mathrm{C}_{\mathrm{NO}_{3}}{ }^{-}$are the respective concentrations in the water column, $D_{\mathrm{O}_{2}}$ and $D_{\mathrm{NO}_{3}}{ }^{-}$are the respective coefficients of diffusion, and $\alpha$ is the ratio between the volume specific denitrification and oxygen respiration rates. The model is based on the fact that $D_{w}$ depends on the water column $\mathrm{NO}_{3}{ }^{-}$concentration, the volume specific denitrification rate in the anoxic zone, and the length of the diffusion path through the oxic zone. The thickness of the oxic zone, in turn, is a function of $\mathrm{O}_{2}$ uptake and $\mathrm{O}_{2}$ concentration in the water column, assuming the same volume specific $\mathrm{O}_{2}$ consumption rate throughout the oxic zone. The diffusion coefficients $D_{\mathrm{NO}_{3}}$ - and $D_{\mathrm{O}_{2}}$ need not to be measured since the ratio between them is invariably 0.8 in an aquatic medium. The volume specific denitrification and oxygen respiration rates are not determined either, but the ratio between them $(\alpha)$ is set to 0.8 on the basis of bacterial kinetics and microsensor studies (Christensen et al. 1989). As demonstrated in Fig. 8, the measured rates of $D_{w}$ corresponded very well with the rates predicted by the model. Denitrification based on $\mathrm{NO}_{3}{ }^{-}$may therefore be estimated by this model using easily obtainable parameters such as $\mathrm{O}_{2}$ consumption and water column $\mathrm{O}_{2}$ and $\mathrm{NO}_{3}{ }^{-}$concentrations.

$D_{\mathrm{n}}$ activity is related to the nitrification rate and the efficiency with which the nitrification process is coupled to denitrification. In the sediment from Kertinge Nor,

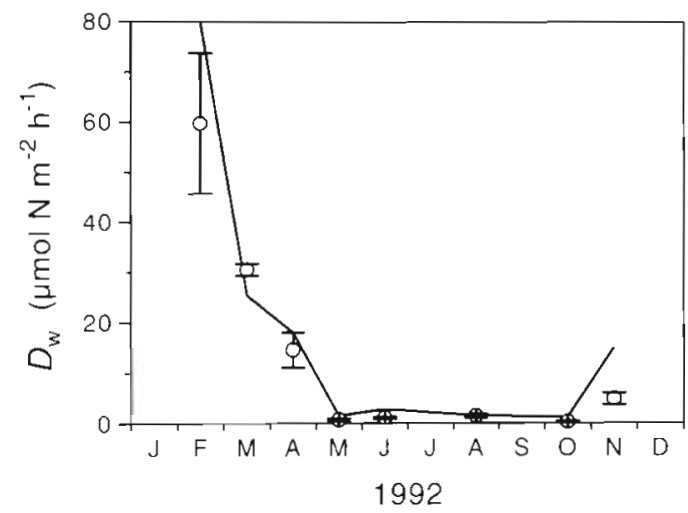

Fig. 8. Measured (circles) and predicted (line) $D_{w}$ (denitrification rate based on $\mathrm{NO}_{3}{ }^{-}$from the water column) during 1992 Error bars indicate SE $(\mathrm{n}=5)$ the highest rates of coupled nitrification-denitrification were observed during the cold months, when the temperature was below $4^{\circ} \mathrm{C}$ (Fig. $4 \mathrm{~B}$ ). Total micrabial respiration in the sediment is reduced by the cold temperatures, thereby reducing total sediment $\mathrm{O}_{2}$ consumption. Oxygen penetration within the sediment is therefore enhanced during winter (Rasmussen \& Jørgensen 1992), which may activate nitrifying bacteria located deeper in the sediment, and thereby enhance total nitrification activity. A seasonal horizontal shift that ensures maximal nitrifying activity in the deeper sediment layers during winter will result in tight coupling between nitrification and denitrification in this part of the year, as demonstrated by Rysgaard et al. (1994) and Jensen et al. (1994).

Denitrification based on water phase $\mathrm{NO}_{3}{ }^{-}$and denitrification coupled to nitrification within the sediment both played an important role in nitrogen removal from Kertinge Nor estuary. At the shallow, sandy sampling site, $D_{\mathrm{w}}$ accounted for ca $50 \%$ of total annual denitrification. It has previously been stated that coupled nitrification-denitrification is the most important denitrification process in aquatic sediments (Seitzinger 1988). However, the present study indicates that $D_{\mathrm{w}}$ may be important in shallow coastal systems that receive significant nutrient input. Moreover, as the study also demonstrates, the relative importance of the 2 processes may change dramatically throughout the year: In February, when $\mathrm{NO}_{3}^{-}$was present in high concentrations, $D_{w}$ accounted for more than $80 \%$ of the total denitrification, while in the summer months, almost all denitrification was due to coupled nitrificationdenitrification (Fig. 4).

We conclude that benthic microalgae may have a strong regulating effect on the efflux of nutrients from the sediment surface to the overlying water in shallow estuarine waters. Due to their assimilatory demand, they may efficiently reduce the flux of inorganic nutrients during the day and may also cause significant uptake of, for example, $\mathrm{NO}_{3}^{-}$from the water column. From this and previous studies it is evident that the presence of benthic microalgae also has a marked influence on the diurnal and seasonal variation in sediment denitrification. The rather complex means whereby they regulate these processes can be summarized as follows. (1) Oxygen production by benthic microalgae increases the oxic zone within the sediment, thereby lengthening the diffusional path for $\mathrm{NO}_{3}{ }^{-}$from the water column to the anoxic denitrification zone and hence reducing denitrification activity based on water phase $\mathrm{NO}_{3}^{-}\left(D_{\mathrm{w}}\right)$. (2) When inorganic nitrogen is present in excess, benthic oxygen production stimulates nitrification and the increased oxic surface layers caused by benthic primary production may stimulate coupled nitrification-denitrification $\left(D_{n}\right)$. 
(3) During summer, when the water column concentration of $\mathrm{NO}_{3}{ }^{-}$and $\mathrm{NH}_{4}{ }^{+}$is low, there is strong competition for inorganic nitrogen between benthic microalgae, nitrifiers and denitrifiers. In this situation benthic primary production will reduce nitrification activity and thereby $D_{n}$, and nitrogen assimilation can decrease the activity of $D_{w}$ as well.

A further conclusion to be drawn from this study is that bioturbation by benthic infauna can significantly stimulate sediment oxygen consumption, $D_{w}$ and $D_{n}$ within the sediment as long as excess inorganic nitrogen is present in the water column. However, since benthic infauna density is generally highest during summer, when the $\mathrm{NO}_{3}{ }^{-}$concentration is low, their effect on $D_{w}$ will be of minor importance on an annual basis. Moreover, as the nitrification potential of sediment in shallow coastal waters is reduced during summer, the stimulatory effect on $D_{n}$ of bioturbation by benthic infauna will also be of minor importance on an annual basis.

Acknowledgements. We thank Tage Dalsgaard for helpful discussions and Pia Nygård Christensen, Kitte Gerlich, Marlene Jessen and Lars Moller for valuable technical assistance. This research was supported by the Danish Agency of Environmental Protection through the Marine Research 90 programme.

\section{LITERATURE CITED}

Aller RC (1982) The effects of macrobenthos on chemical properties of marine sediment and overlying water in animal-sediment relations. McCall PL, Tevesz MJS (eds). Plenum Press, New York, p 53-102

Aller RC (1988) Benthic fauna and biogeochemical processes in marine sediments: the role of burrow structures. In Blackburn TH, Sørensen J (eds) Nitrogen cycling in coastal marine environments. John Wiley and Sons Ltd, Chichester, p 301-338

Bower E, Hansen HA (1980) A salicylate-hypochlorite method for determining ammonia in seawater. Can J Fish Aquat Sci 37:794-798

Broast CW, Mulvaney RL, Baveye P (1988) Evaluation of nitrogen-15 tracer techniques for direct measurements of denitrification in soil: 1. Theory. Soil Sci Soc Am J 52: $1317-1322$

Christensen PB (ed) (1994) Nutrient transport and dynamics in Kertinge Nor/Kerteminde Fjord, Denmark. The Marine Research 90 Programme No. 43. The Danish Agency of Environmental Protection (in Danısh with English summary)

Christensen PB, Nielsen LP, Revsbech NP, Sorensen J (1989) Microsonation of denitrification activity in stream sediments as studied with a combined oxygen and nitrous oxide microsensor. Appl environ Microbiol 55(5):1234-1241

Christensen PB, Nielsen LP, Serensen J, Revsbech NP (1990) Denitrification in nitrate-rich streams: diurnal and seasonal variation related to benthic oxygen metabolism. Limnol Oceanogr 35(3):640-651

Grasshoff K, Erhardt M, Kremling K (1983) Methods of seawater analysis, 2nd edn. Verlag Chemie, Weinheim

Hansen JI, Henriksen K, Blackburn TH (1981) Seasonal dis- tribution of nitrifying bacteria and rates of nitrification in coastal marine sediments. Microb Ecol 7:297-304

Henriksen K, Hansen J, Blackburn TH (1980) The influence of benthic infauna on exchange rates of inorganic nitrogen between sediment and water column. Ophelia (Suppl) 1: $249-256$

Henriksen K, Hansen JI, Blackburn TH (1981) Rates of nitrification, distribution of nitrifying bacteria, and nitrate fluxes in different types of sediment from Danish waters. Mar Biol 61:299-304

Henriksen K, Kemp W (1988) Nitrification in estuarine and coastal marine sediments. In: Blackburn TH, Sørenson J (eds) Nitrogen cycling in coastal marine environments. John Wiley and Sons, p 201-249

Jenkins MC, Kemp WM (1984) The coupling of nitrification and denitrification in two estuarine sediments. Limnol Oceanogr 29:609-619

Jensen K, Sloth NP, Risgaard-Petersen N, Rysgaard S, Revsbech NP (1994) Estimation of nitrification and denitrification from microprofiles of sediment. Appl environ Microbiol 60:2094-2100

Kristensen E (1984) Effect of natural concentrations of nutrient exchange between a polychaete burrow in estuarine sediment and the overlying water. J exp mar Biol Ecol 75: $171-190$

Kristensen $E_{\text {, Jensen }} \mathrm{MH}$, Aller C (1.991) Direct measurements of dissolved inorganic nitrogen exchange and denitrification in individual polychaete (Nereis virens) burrows. J mar Res 49:355-377

Nielsen LP (1992) Denitrification in sediment determined from nitrogen isotope paring. FEMS Microbiol Ecol 86: $357-362$

Nielsen LP, Chrıstensen PB, Revsbech NP, Sørensen J (1990) Denitrification and photosynthesis in stream sediment studied with microsensor and whole-core technique. Limnol Oceanogr 35(5): 1135-1144

Nielsen LP, Sloth N.P (1994) Denitrification, nitrification and nitrogen assimilation in photosynthetic microbial mats. In: Stahl LJ, Caumette P (eds) Microbial mats, structure, development and environmental significance. NATO ASI Series G, Ecological Sciences, Vol 35. Springer Verlag, Berlin, p 319-324

Nishio T, Koike I, Hattori A (1983) Estimation of denitrification and nitrification in coastal and estuarine sediments Appl environ Microbiol 45:444-450

Pelegri SP, Nielsen LP, Blackburn TH (1994) Denitrification in estuarine sediment stimulated by the irrigation activity of the amphipod Corophium volutator. Mar Ecol Prog Ser 105:285-290

Rasmussen H, Jørgensen BB (1992) Microelectrode study of seasonal oxygen uptake in a coastal sediment; role of molecular diffusion. Mar Ecol Prog Ser 81:289-303

Revsbech NP, Jorgensen BB (1983) Photosynthesis of benthic microflora measured with high spatial resolution by the oxygen microprofile method: capabilities and limitations of the method. Limnol Oceanogr 28:749-756

Rhoads DC (1974) Organism-sediment relations on the muddy sea floor. Oceanogr mar Biol A Rev 12:263-300

Risgaard-Petersen N, Rysgaard S, Revsbech NP (1993) A sensitive assay for determination of ${ }^{14} \mathrm{~N} /{ }^{15} \mathrm{~N}$ isotope distribution in $\mathrm{NO}_{3}{ }^{-} \mathrm{J}$ microbiol Meth 17:155-164

Risgaard-Petersen N, Rysgaard S, Nielsen LP, Revsbech NP (1994) Diurnal variation of denitrification in sediments colonized by benthic microphytes. Limnol Oceanogr 39: $573-579$

Rysgaard S, Risgaard-Petersen N, Nielsen LP, Revsbech NP (1993) Nitrification and denitrfication in lake and estu- 
arine sediments measured by ${ }^{15} \mathrm{~N}$ dilution technique and isotope pairing. Appl environ Biol 59(7):2093-2098

Rysgaard S, Risgaard-Petersen N, Sloth NP, Jensen K, Nielsen LP (1994) Oxygen regulation of nitrification and denitrification in treshwater sediments. Limnol Oceanogr 39: $1643-1652$

Seitzınger SP (1988) Denitnfication in freshwater and coastal marine ecosystems: ecological and geochemical significance. Limnol Oceanogr 33:702-724

This article was submitted to the editor
Sundbäck K (1986) What are the benthic microalgae doing on the bottom of Lahom Bay? Ophelia (Suppl) 4:273-286

Sundbáck K, Granéli W (1988) Influence of microphytobenthos on the nutrient flux between sediment and water: a laboratory study. Mar Ecol Prog Ser 43:63-69

Vanderborght JP, Billen G (1975) Vertical distribution of nitrate concntration in interstitial water of marine sediments with nitrification and denitrification. Limnol Oceanogr 20 : $953-961$

Manuscript first received: October 26. 1994

Revised version accepted: April 5, 1995 